\title{
Hubungan antara Gaya Hidup Sehat dengan Tingkat Stres Siswa Kelas XII SMA Negeri di Denpasar Menjelang Ujian Nasional Berdasarkan Strategi Coping Stres
}

\author{
Nyoman Adi Krisna Wibawa dan Putu Nugrahaeni Widiasavitri, S.Psi.,M.Psi. \\ Program StudiPsikologi, Fakultas Kedokteran, UniversitasUdayana \\ Adikrisna_wibawa@yahoo.co.id
}

\begin{abstract}
Abstrak
Ujian Nasional adalah standar nilai kelulusan yang telah ditetapkan pemerintah untuk memenuhi kompetensi pendidikan secara Nasional. Siswa yang menanamkan nilai-nilai positif pada gaya hidup sehat dalam kehidupan sehariharinya, maka akan mampu memanajemen diri dengan strategi coping yang tepat untuk keluar dari situasi stres yang menekan. Penelitian kuantitatif dengan metode analisis regresi linier sederhana bertujuan untuk melihat hubungan antara gaya hidup sehat dengan tingkat stres siswa kelas XII SMA Negeri di Denpasar menjelang Ujian Nasional berdasarkan strategi coping stres pada kelompok yang berorientasi pada masalah (problem focused coping) dan kelompok berorientasi pada emosi (emotion focused coping).

Teknik sampling menggunakan cluster random sampling dengan 317 subjek siswa SMA Negeri kelas XII di Denpasar. Alat ukur dalam penelitian ini adalah skala gaya hidup sehat (realibilitas 0,846 ), skala tingkat stres (realibilitas 0,913 ), dan skala strategi coping stres (realibilitas 0,868 ).

Uji z-skor dan analisis regresi digunakan membagi kelompok strategi coping dengan 143 subjek pada problem focused coping $(\mathrm{p}<0,05)$ dengan persamaan regresi $\mathrm{Y}=75,018-0,556 \mathrm{X}$ sedangkan pada emotion focused coping sebanyak 112 subjek $(\mathrm{p}<0,05)$ dengan persamaan regresi $\mathrm{Y}=88,748-0,440 \mathrm{X}$.

Nilai korelasi R pada kelompok problem focused coping adalah sebesar 0,876 dan pada kelompok emotion focused coping adalah sebesar 0,844 . Maka ada hubungan antara gaya hidup sehat dan tingkat stres pada kelompok strategi problem focused coping dan emotion focused coping yang tergolong ke dalam hubungan yang sangat kuat dan penggunaan problem focused coping lebih efektif dibandingkan emotion focused coping hubungannya antara gaya hidup sehat dengan tingkat stres siswa kelas XII SMA Negeri di Denpasar menjelang Ujian Nasional.
\end{abstract}

Kata kunci : tingkat stres, gaya hidup sehat, strategi coping, Ujian Nasional

\begin{abstract}
National examination is a standard passing score that has been set by the government to meet national educational competencies. Students who implant the positive values to healthy lifestyle in their daily lives, it will be able to manage themselves with appropriate coping strategies to get out of stressful situations that push. Quantitative research with regression analysis method aimed to see the relationship between healthy lifestyle with stress level of twelfth grade students of high school in Denpasar towards final examination based on stress coping strategy, like problem focused coping and emotion focused coping.
\end{abstract}

Sampling technique uses cluster random sampling with 317 subjects of twelfth grade students in Denpasar. Measuring instrument in this study is the healthy lifestyle scale (reliability 0.846), stress level scale (reliability 0.913), and stress coping strategies scale (reliability 0.868 ).

Z-score test and regression analysis were used to divide into groups with 143 subjects coping strategies in problem focused coping $(\mathrm{p}<0.05)$ with a regression equation $\mathrm{Y}=75.018-0.556 \mathrm{X}$ while on emotion focused coping were 112 subjects $(\mathrm{p}<0.05)$ the regression equation $\mathrm{Y}=88.748-.440 \mathrm{X}$, then there is a relationship between a healthy lifestyle in problem focused coping strategies group and emotion focused coping with stress levels at high school students especially for twelfth grade before the National examination.

Score of R correlation on group problem focused coping is 0.876 and the group emotion focused coping is 0.844 . Then the relationship between a healthy lifestyle and stress levels in group problem focused coping strategies and emotion focused coping belong to strongest relationship between the two groups (problem and emotion focused coping). Uses problem focused coping more efective than emotion focused coping to see the relationship between healthy lifestyle with stress level of twelfth grade students of high school in Denpasar towards final examination.

Keywords: stress levels, a healthy lifestyle, coping strategies, the National examination 


\section{N. A. K. WIBAWA DAN P. N. WIDIASAVITRI}

\section{LATAR BELAKANG}

Pendidikan merupakan suatu bagian yang sangat penting dalam kehidupan manusia, dimana melalui pendidikan dapat membentuk sumber daya manusia yang berkualitas baik dari segi spiritual, intelegensi dan kemampuan (skill). Lembaga pemerintah khususnya di bidang pendidikan mencanangkan program Ujian Nasional sebagai suatu standar dan pemetaan secara merata bagi para siswa sekolah untuk mengantisipasi dan memenuhi perkembangan tuntutan globalisasi. Ujian Nasional adalah merupakan standar nilai kelulusan yang telah ditetapkan pemerintah untuk mencapai nilai pencapaian kompetensi lulusan secara Nasional pada mata pelajaran tertentu dalam kelompok mata pelajaran ilmu pengetahuan dan teknologi (Disdikpora, 2013).

Fakta yang menarik perhatian mengenai presentase kelulusan Ujian Nasional terutama yang diselenggarakan di Provinsi Bali adalah selalu mendapat peringkat terbaik dalam meluluskan siswa-siswanya terutama siswa yang sedang berada pada jenjang akhir Sekolah Menengah Atas (SMA). Terbukti sejak tahun 2005 pada mata pelajaran IPA di SMA, Bali menduduki peringkat I peraihan nilai rata-rata nasional (total nilai 22,24), mengungguli Jawa Timur, Sulawesi Utara, Sumatera Selatan, Jawa Barat dan DKI Jakarta. Sementara dalam bidang Bahasa di SMA, Bali menduduki peringkat IV (total nilai 21,53). Sedangkan dalam bidang IPS, Bali peringkat VII dengan total nilai 19,29 (Bali Post, 2005). Hingga berlanjut pada tiga tahun terakhir, Bali tetap menjadi pemegang peringkat terbaik dalam meluluskan siswasiswanya. Terbukti pada periode tahun 2010/2011 catatan Ujian Nasional di Bali menunjukkan sepuluh siswa $(0,04$ persen) mengalami ketidaklulusan dari total 24.290 siswa yang mengikuti Ujian Nasional dengan nilai rata-rata nilai Ujian nasional tertinggi pada skala Provinsi yaitu 8,08 , sedangkan pada periode Ujian Nasional tahun 2011/2012, Bali mengalami sedikit kemunduran dengan presentase tingkat kelulusan yang meningkat menjadi 26 siswa yang tidak lulus $(0,10$ persen $)$, tetapi Bali menempatkan dua sekolah yang menjadi daftar sepuluh nilai Ujian Nasional tertinggi di seluruh Indonesia, yaitu SMA Negeri 4 Denpasar dan SMA Negeri 1 Denpasar (Reymond, 2012).

Pada periode tahun 2012/2013, tingkat kelulusan siswa pada Ujian Nasional SMA/MA mencapai 99,95 persen atau meningkat 0,05 persen dibandingkan tahun sebelumnya. Kepala Dinas Pendidikan, Pemuda, dan Olahraga (Disdikpora) Provinsi Bali Anak Agung Gede Ngurah Sujaya mengatakan dengan tingkat kelulusan tersebut, tercatat

13 siswa yang tidak lulus dari total 26.246 siswa peserta UN SMA/MA. Terdapat tiga siswa yang terdaftar dalam 10 peringkat nilai Ujian Nasional tertinggi pada tingkat Nasional, yaitu dua siswa berasal dari SMA Negeri 4 Denpasar dan satu orang berasal dari SMA Negeri 1 Denpasar (Badudu, 2012). Pada periode 2013/2014 adalah menurut
Departemen Pendidikan dan Kebudayaan persentase kelulusan siswa pada jenjang SMA/SMK adalah mencapai 99,97 persen dengan prestasi gemilang yang diraih oleh SMA Negeri 4 Denpasar yang menempatkan beberapa siswanya menduduki daftar 12 siswa dengan nilai tertinggi pada peringkat Nasional (Afifah, 2013).

Ujian Nasional rutin diadakan setiap satu tahun sekali diakhir periode belajar setiap sekolah, namun tetap saja menjelang pelaksanaan Ujian Nasional menciptakan berbagai bentuk tekanan yang menyebabkan siswa menjadi stres. Menurut Lazarus \& Folkman (1984) mengartikan stres secara luas adalah sebagai sebuah hubungan antara seseorang dengan lingkungannya yang dinilai melebihi kemampuan dan mengancam hidupnya. Menurut Corbin, Welk, Corbin, dan Welk (2008) mengartikan stres adalah sebagai suatu respon yang tidak spesifik (adaptasi secara umum) yang dikeluarkan oleh tubuh untuk tetap menjaga keseimbangan dari fungsi fisiologis. Menurut Potter, dkk (dalam Taylor, 2009) menyatakan bahwa untuk menilai besaran tingkat stres yang dialami individu dapat dilihat berdasarkan indikator gejala stres, antara lain sebagai berikut seperti : Gejala fisiologis, yaitu stres yang ditimbulkan dari gejala objektif yang melibatkan sistem saraf dan sistem endokrin; Gejala perilaku, yaitu akibat stres yang ditampakkan melalui perilaku atau kegiatan-kegiatan fisik yang dapat diamati atau terlihat; Gejala emosional, yaitu akibat stres yang ditampakan melalui perasaan dan perilaku dalam diri individu; Gejala kognitif, yaitu stres yang berdampak terhadap fungsi kerja otak dan pikiran; dan Gejala interpersonal, yaitu stres yang berdampak terhadap hubungan individu dengan orang lain. Gejala-gejala yang ditunjukan oleh individu berbeda dari biasanya menandakan bahwa individu tersebut mengalami tekanan yang disebabkan oleh stimulus yang menyebabkan stres, khususnya stres siswa menjelang persiapan Ujian Nasional.

Ari (2012) pada liputan khusus Harian Jogja, menyimpulkan beberapa hal yang menjadi faktor penyebab siswa menjadi stres ketika menghadapi stres Ujian Nasional adalah bukan hanya berasal dari dalam diri siswa atau lingkungan keluarga saja, tetapi perbedaan sistem belajar yang diterapkan setiap sekolah menyebabkan anak menjadi tertekan sebelum Ujian Nasional diadakan. Setiap sekolah menerapkan pola pembelajaran melalui ujian try-out, pemantapan sekolah, maupun ujian-ujian dalam bentuk lainnya bertujuan untuk memotivasi siswa agar mencapai standar kelulusan yang diharapkan oleh Departemen Pendidikan. Keadaan yang membuat siswa terus digenjot dengan pemberian ujian-ujian try-out rutin dan materi pelajaran berdampak pada jadwal siswa yang semakin padat di sekolah terlebih lagi jika terdapat orang tua siswa yang memasukan anaknya untuk mengikuti kegiatan bimbingan belajar di luar sekolah, tidak menutup kemungkinan timbulnya kelemahan-kelemahan yang berpengaruh negatif pada diri siswa. 


\section{N. A. K. WIBAWA DAN P. N. WIDIASAVITRI}

Jika dipandang dari sisi positifnya, dampak yang terjadi berdasarkan peristiwa diatas adalah provinsi Bali khususnya kota Denpasar memiliki sumber daya manusia sebagai penerus generasi bangsa yang memiliki potensi berkualitas dan mampu bersaing dalam tantangan perkembangan globalisasi dunia (Mahagangga, 2010). Namun, disamping itu, tersirat tantangan yang cukup besar bagi pihakpihak yang terlibat di dalam dunia pendidikan, seperti departemen atau instansi pendidikan guna mempertahankan pendidikan yang unggul dan berkualitas dari tahun-tahun sebelumnya. Hal ini akan berimbas kembali pada cara pengajaran di sekolah dengan jadwal yang lebih diperketat dan tidak fleksibel kepada siswa-siswanya menjelang menghadapi Ujian Nasional, sehingga para siswa hanya menyesuaikan saja, tidak mengembangkan cara belajar yang diberikan oleh pihak sekolah.

Peneliti juga melakukan survei wawancara dengan pertanyaan terbuka pada saat 3 bulan sebelum berlangsungnya Ujian Nasional, yaitu pada bulan Februari 2013 untuk memperkuat data acuan dalam melakukan penelitian. Hasil yang didapat menyatakan dari 4 siswa yang diwawancara mewakili sekolahnya yang ada di kawasan Denpasar mengaku pada saat diwawancara merasa kurang percaya diri pada persiapannya menghadapi Ujian Nasional, selain itu beberapa siswa mengaku kurang cukup tidur, tidak teratur dalam menjaga kondisi tubuh, baik berolahraga, dan menjaga nutrisi makanan yang dimakan. Beberapa siswa juga terkadang memperlihatkan emosi yang kurang wajar dengan menjadi lebih pendiam dan kurang peduli terhadap situasi yang berada di sekitarnya, terlebih lagi ketika berhadapan dengan orang lain kurang dapat mengontrol emosi menjadi lebih sensitif dan mudah cepat mengeluarkan emosi marah.

Hal tersebut, disebabkan oleh jadwal belajar yang diberlakukan oleh sekolah yang cukup padat terlebih lagi ke 4 siswa yang diwawancara semuanya mengikuti pelajaran tambahan di luar sekolah karena keinginan orang tua. Disamping itu, yang menjadi faktor utama adalah perbedaan sistem Ujian Nasional dari lembaga pemerintahan Dinas Pendidikan yang berbeda dari tahun sebelumnya, yang dulunya 5 paket soal berbeda sekarang menjadi 20 paket soal berbeda setiap kelasnya dan isu tersebarnya kunci jawaban palsu menurut beberapa siswa sangat meresahkan. Siswa beranggapan mengenai beberapa gaya hidup yang tidak sehat dirasakan menjelang Ujian Nasional adalah seperti sulit untuk melakukan tidur tepat waktu, jarang atau sama sekali tidak melakukan aktivitas berolahraga, tidak memiliki nafsu makan, jarang mementingkan kesehatan, dan kurang berkomunikasi dengan keluarga ketika berada di lingkungan keluarga.

Menurut Departemen Kesehatan Republik Indonesia (1997), gaya hidup sehat adalah segala upaya untuk menerapkan kebiasaan yang baik dalam menciptakan hidup yang sehat dan menghindari kebiasaan buruk yang dapat mengganggu kesehatan. Menurut Hwang (dalam Akbar, 2012) beberapa indikator sebagai penentu individu dalam melakukan gaya hidup sehat, yaitu kebugaran fisik dalam berolahraga, pola makan seimbang, kegiatan produktif dan sosial, waktu luang, kegiatan sehari-hari, manajemen stres dan partisipasi spiritual, dan promosi kesehatan dan perilaku berisiko. Terkait dengan stres menjelang menghadapi Ujian Nasional bahwa siswa yang sudah menanamkan nilai-nilai positif gaya hidup sehat dalam kehidupan sehari-harinya, maka akan mampu memanajemen diri dengan strategi coping yang tepat untuk keluar dari situasi stres yang menekan.

Strategi koping stres adalah merupakan sebuah perubahan kognitif dan perilaku secara konstan dalam upaya untuk mengatasi tuntutan internal dan atau eksternal khusus yang melelahkan atau melebihi sumber individu (Lazarus \& Folkman, 1984). Bentuk strategi koping stres dibagi menjadi 2 dimensi, yaitu problem focused coping dengan penjabaran indikator seperti confronting, accepting responsibility, planfull problem solving, dan positive reappraisal dan emotion focused coping dengan penjabaran indikator seperti distancing, self controling, dan escape avoidance. Setiap individu khususnya siswa akan memiliki cara-cara tersendiri yang berbeda dalam menghadapi stres Ujian Nasional, tergantung dari seberapa besar siswa tersebut menilai stimulus yang menyebabkan stres dan kemampuan individu menghadapi situasi yang menekan. Peneliti memiliki harapan melalui penelitian ini, untuk dapat menanamkan sisi psikologis di dalam diri siswa agar lebih percaya diri dan memotivasi siswa dalam menghadapi Ujian Nasional melalui salah satu cara yaitu menerapkan pola gaya hidup sehat dan penggunaan strategi coping yang tepat dalam menghadapi stres Ujian Nasional.

\section{METODE}

\section{Variabel dan definisi operasional}

Penelitian ini menggunakan penelitian kuantitatif dengan menggunakan variabel bebas, variabel tergantung, dan variabel moderator. Variabel bebas merupakan variabel yang diduga mempengaruhi atau yang menjadi sebab perubahan timbulnya variabel dependen atau terikat (Sugiyono, 2009). Variabel bebas dalam penelitian adalah variabel gaya hidup sehat. Variabel tergantung merupakan variabel yang diduga dipengaruhi atau yang menjadi akibat, karena adanya variabel bebas (Sugiyono, 2009). Variabel tergantung dalam penelitian adalah variabel tingkat stres. Variabel moderator merupakan variabel yang mempengaruhi (memperkuat atau memperlemah) hubungan antara variabel bebas dengan variabel tergantung (Sugiyono, 2009). Variabel moderator dalam penelitian adalah vaariabel strategi koping stres.

Definisi operasional dari variabel gaya hidup sehat adalah keadaan inidividu yang diakibatkan dari kebiasan hidup yang baik yang ditunjukan dengan perilaku hidup yang sehat, 
terawat, dan terjaga yang dilandaskan dengan pengetahuan dan infomasi yang tepat. Peneliti menggunakan skala ukur gaya hidup sehat untuk mengukur variabel gaya hidup sehat dengan indikator perilaku yang dimodifikasi berdasarkan aspek gaya hidup sehat menurut teori Hwang (dalam Akbar, 2012) dengan jumlah aitem 26 aitem adalah kebugaran fisik dalam berolahraga, pola makan seimbang, kegiatan produktif dan sosial, waktu luang, kegiatan sehari-hari, manajemen stres dan partisipasi spiritual, dan promosi kesehatan dan perilaku berisiko.

Pada skala pengukuran gaya hidup sehat, peneliti menggunakan skala Likert dengan rentang skala sikap 1 sampai dengan 4 dengan jumlah aitem sebanyak 26 buah aitem, sehingga jumlah total skor tertinggi pada skala pengukuran tingkat stres adalah sebesar 104 dan minimal skor sebesar 26. Peneliti menyatakan semakin tinggi nilai skor pada skala pengukuran gaya hidup sehat maka semakin baik kebiasaan hidup sehat yang diterapkan subjek atau siswa SMA kelas XII dalam kondisi menjelang Ujian Nasional, sedangkan semakin kecil nilai skor pada skala pengukuran gaya hidup sehat maka semakin buruk kebiasaan hidup sehat yang diterapkan subjek atau siswa SMA kelas XII dalam kondisi menjelang Ujian Nasional.

Definisi operasional mengenai tingkat stres adalah keadaan yang timbul akibat situasi yang tidak menyenangkan terhadap suatu respon yang tidak spesifik yang disebabkan oleh sebuah stimulus (sebagai sumber tekanan). Peneliti menggunakan skala ukur tingkat stres yang diadaptasi dari penelitian yang dilakukan Hamdiana (2009), dimana mengkategorisasikan tingkatan stres berdasarkan tanda dan gejala fungsi fisiologis, perilaku, emosional, kognitif, dan interpersonal (Potter \& Perry dalam Taylor, 2009). Hasil pengukuran pada tingkat stres dibagi menjadi 5 bagian stres, yaitu normal, ringan, sedang, berat, dan sangat berat (Lovibond \& Lovibond, 1996).

Pada skala pengukuran tingkat stres, peneliti menggunakan skala Likert dengan rentang skala sikap 1 sampai dengan 4 dengan jumlah aitem sebanyak 25 buah aitem, sehingga jumlah total skor tertinggi pada skala pengukuran tingkat stres adalah sebesar 100 dan minimal skor sebesar 25. Peneliti menyatakan semakin tinggi nilai skor pada skala pengukuran tingkat stres maka semakin tinggi tingkat stres pada subjek atau siswa SMA kelas XII atau tergolong ke dalam tingkat stres sangat berat, sedangkan semakin kecil nilai skor pada skala pengukuran tingkat stres maka semakin kecil tingkat stres pada subjek atau siswa SMA kelas XII dan tergolong ke dalam tingkat stres normal.

Definisi operasional strategi koping stres adalah kemampuan individu untuk mengatur dan mengelola perubahan kognitif dan perilaku secara konstan dalam upaya untuk mengatasi tuntutan internal atau eksternal yang melelahkan atau melebih sumber individu. peneliti membagi menjadi dua bentuk dimensi variabel yang memodifikasi berdasarkan indikator perilaku "Ways of Coping” dari teori Lazarus (dalam Taylor, 2009), yaitu problem focused coping (accepting, confronting, planfull problem dolving, dan positive appraisal) dan eemotion focused coping (distancing, self controlling, dan escape avoidance) dengan menggunakan nilai z-score dengan total 26 aitem.

\section{Respoanden}

Populasi adalah wilayah generalisasi yang terdiri atas obyek/subjek yang mempunyai kualitas dan karakteristik tertentu yang ditetapkan oleh peneliti untuk dipelajari kemudian ditarik kesimpulannya (Sugiyono, 2007). Populasi yang digunakan peneliti adalah siswa SMA kelas XII SMA Negeri di Denpasar. Jumlah total populasi pada siswa kelas XII SMA Negeri di Denpasar adalah 3.117 siswa. Sedangkan sampel adalah bagian dari jumlah dan karakteristik yang dimiliki oleh populasi (Azwar, 2004). Yang menjadi sampel subjek penelitian adalah sebagian siswa SMA kelas XII di Denpasar dengan jenis kelamin laki-laki maupun perempuan.

Dalam menentukan jumlah sampel peneliti menggunakan teori Isaac dan Michael dengan jumlah total sampel 317 siswa (Sugiyono, 2007). Sampel yang diambil dari populasi menggunakan teknik cluster random sampling. Teknik cluster random sampling adalah merupakan teknik probability sampling yang digunakan untuk menentukan unit sampel yang diinginkan adalah kelompok kecil dari unit-unit elementer yang masih bersifat heterogen (Nazir, 1988).

\section{Tempat penelitian}

Penelitian yang dilakukan bertempat di masingmasing sekolah yang termasuk ke dalam sekolah rayon/wilayah Denpasar, Bali. Waktu pelaksanaan dilakukannya penelitian adalah berkisar dari bulan Februari sampai dengan akhir bulam Maret 2013. Penyebaran kuesioner dilakukan di beberapa sekolah, seperti SMA Negeri 8 Denpasar, SMA Negeri 3 Denpasar, SMA Negeri 2 Denpasar, dan SMA Negeri 7 Denpasar.

\section{Alat ukur}

Pada skala pengukuran gaya hidup sehat, peneliti menggunakan skala Likert dengan rentang skala sikap 1 sampai dengan 4 dengan jumlah aitem sebanyak 26 buah aitem, sehingga jumlah total skor tertinggi pada skala pengukuran tingkat stres adalah sebesar 104 dan minimal skor sebesar 26. Indikator pada skala gaya hidup sehat adalah sebagai berikut, seperti : kebugaran fisik dalam berolahraga, pola makan seimbang, kegiatan produktif dan sosial, waktu luang, kegiatan sehari-hari, manajemen stres dan partisipasi spiritual, dan promosi kesehatan dan perilaku berisiko.

Pada skala pengukuran tingkat stres, peneliti mengadaptasi dari penelitian yang dilakukan Hamdiana 


\section{N. A. K. WIBAWA DAN P. N. WIDIASAVITRI}

(2009), dimana mengkategorisasikan tingkatan stres berdasarkan tanda dan gejala fungsi fisiologis, perilaku, emosional, kognitif, dan interpersonal (Potter \& Perry dalam Taylor, 2009). Hasil pengukuran pada tingkat stres dibagi menjadi 5 bagian stres, yaitu normal, ringan, sedang, berat, dan sangat berat (Lovibond \& Lovibond, 1996). Pada skala pengukuran tingkat stres, peneliti menggunakan skala Likert dengan rentang skala sikap 1 sampai dengan 4 dengan jumlah aitem sebanyak 25 buah aitem, sehingga jumlah total skor tertinggi pada skala pengukuran tingkat stres adalah sebesar 100 dan minimal skor sebesar 25. Peneliti menyatakan semakin tinggi nilai skor pada skala pengukuran tingkat stres maka semakin tinggi tingkat stres pada subjek atau siswa SMA kelas XII atau tergolong ke dalam tingkat stres sangat berat, sedangkan semakin kecil nilai skor pada skala pengukuran tingkat stres maka semakin kecil tingkat stres pada subjek atau siswa SMA kelas XII dan tergolong ke dalam tingkat stres normal.

Pada skala pengukuran strategi koping stres, peneliti mengukur dengan menggunakan skala likert dengan total item sebanyak 26 item dengan memodifikasi berdasarkan indikator perilaku "Ways of Coping" dari teori Lazarus (dalam Taylor, 2009) dengan membagi menjadi dua bentuk dimensi variabel, yaitu problem focused coping (accepting, confronting, planfull problem dolving, dan positive appraisal) dan eemotion focused coping (distancing, self controlling, dan escape avoidance). Peneliti menganalisis hasil alat ukur dengan menggunakan nilai z-score.

\section{Metode pengumpulan data}

Metode pengumpulan data yang digunakan dalam penelitian ini adalah metode penyebaran angket isian (Questionnaire) yang berisikan skala sikap, yaitu skala aitem pertanyaan mengenai gaya hidup sehat, strategi coping, dan skala tingkat stres dengan menggunakan model skala Likert. Dalam penelitian ini ketiga skala tersebut akan langsung diberikan kepada responden penelitian yaitu siswa kelas XII SMA Negeri di Denpasar. Skala sikap menurut Likert terdiri dari pernyataan-pernyataan dengan empat pilihan jawaban yaitu Tidak Pernah (TP), Jarang (J), Sering (S), dan Sangat Sering (SS) (Azwar, 2004, h. 97-98). Keempat pilihan jawaban tersebut diberi skor $\mathrm{TP}=1 ; \mathrm{J}=2 ; \mathrm{S}=3 ; \& \mathrm{SS}=4$; untuk pernyataan favorable, dan $\mathrm{SS}=1 ; \mathrm{S}=2 ; \mathrm{J}=3 ; \mathrm{TP}=4$ untuk pernyataan unfavorable (Azwar, 2004, h. 99).

Di dalam penelitian terdapat variabel bebas yaitu gaya hidup sehat dan variabel tergantung yaitu tingkat stres berdasarkan pengelompokan strategi coping stres sebagai variabel moderator. Sebelum skala sikap tersebut menjadi alat ukur penelitian, peneliti melakukan uji coba subjek tidak terpakai terlebih dahulu di lapangan pada responden dengan karakteristik dan lokasi penelitian yang sama. Jumlah responden yang peneliti gunakan sebagai uji tryout validasi dan reliabilitas sebanyak 60 orang dari total try-out yang disebar sebanyak 69 orang. Pengurangan jumlah sampel menjadi 60 karena respon jawaban yang tidak lengkap diisi dan beberapa jawaban yang muncul ganda. Jumlah minimum sampel adalah 60 adalah diambil dari buku "Validitas dan Reliabilitas" pengarang Azwar (2007). Selain itu peneliti juga menyiapkan formulir informed consent yang dilampirkan sebelum penelitian dilakukan.

\section{Teknik Analisis Data}

Pengujian validitas aitem adalah sejauh mana sebuah alat ukur mampu melakukan fungsi ukurnya, atau memberikan hasil ukur yang akurat dan tepat sesuai dengan tujuan pengukuran tersebut, serta mempunyai kecermatan yang tinggi dalam mengenali perbedaan-perbedaan kecil pada hal yang diukurnya (Azwar, 2000). Batas minimum validitas yang dianggap baik adalah $>0,30$ atau menggunakan batas minimum $\mathrm{r}$ tabel koefisien korelasi Product Moment (Sugiyono, 2007). Validitas dalam penelitian ini adalah validitas konstruk, yaitu menunjukkan sejauh mana suatu alat ukur mampu mengukur apa yang ingin diukur oleh peneliti dan validitas isi, yaitu sejauh mana instrumen atau alat ukur mencerminkan keseluruhan konten atau materi yang diujikan atau yang seharusnya dikuasai secara proporsional (Anzwar, 2000). Pengujian realibilitas aitem adalah uji keterhandalan yang bertujuan untuk mengetahui seberapa jauh suatu alat ukur dapat diandalkan atau dipercaya. Dalam penelitian ini, reliabilitas ditinjau dengan Cronbach's Alpha SPSS 17.0 untuk melihat konsistensi internalnya.

Metode analisis data menggunakan regresi linier, dengan bantuan program SPSS 17. Analisis data ini digunakan untuk mencari arah hubungan antara variabel, sehingga dapat meramalkan atau memprediksi variabel tergantung apabila variabel bebas diketahui (Sugiyono, 2007). Dalam melakukan analisis data, terdapat dua syarat yang harus dipenuhi, yaitu dilakukannya uji asumsi berupa uji normalitas dan uji linearitas dengan alat bantu perangkat lunak SPSS 17.0 (Sugiyono, 2007).

Uji normalitas dilakukan untuk untuk membandingkan persebaran data dengan kurva distribusi normal antara variabel haya hidup sehat dengan tingkat stres pada masing-masing kelompok strategi koping stres (Sugiyono, 2007). Data dinyatakan berdistribusi normal jika signifikansi lebih besar dari 0,05 atau 5\% dimana jika probabilitas atau $\mathrm{p}$ lebih besar dari $0,05(\mathrm{p}>0,05)$ pada uji normalitas dengan Kolmogorov-Smirnov SPSS 17 (Sugiyono, 2007). Uji linieritas dilakukan untuk mengetahui apakah dua variabel mempunyai hubungan yang linier atau tidak secara signifikan. Pengujian pada SPSS dengan melihat nilai test for linearity pada taraf signifikan 0,05. Dua variabel dikatakan mempunyai hubungan yang linier bila signifikan kurang dari 0,05 dimana jika nilai ' $p$ ' lebih kecil dari $0,05(\mathrm{p}<0,05)$ 
(Sugiyono, 2007). Jadi, tujuannya adalah untuk melihat hubungan linear pada variabel bebas dan variabel tergantung (Sugiyono, 2007). Uji linieritas dalam penelitian ini dilakukan dengan menggunakan teknik compare means SPSS 17 dengan melihat nilai test for linearity-nya.

\section{HASIL PENELITIAN}

Sebelum melaksanakan penelitian yang sebenarnya, peneliti memerlukan uji coba kesasihan data (try-out tidak terpakai) pada awal bulan Februari dan terselesaikan pada pertengahan akhir bulan Februari tahun 2013 dengan karakteristik responden yang sesuai dengan model sampel pada populasi dari penelitian. Jumlah responden yang peneliti gunakan sebagai uji tryout validasi dan reliabilitas sebanyak 60 orang dari total try-out yang disebar sebanyak 69 orang. Jumlah responden yang gugur menjadi 60 karena respon jawaban kuesioner yang tidak lengkap diisi dan beberapa jawaban yang muncul ganda (Azwar, 2007).

Berdasarkan hasil validitas dan realibilitas menggunakan responden sebanyak 60 siswa dan nilai harga $r$ kritis product moment sebesar 0,254 pada koefisien validitas, di dapatkan hasil sebagai berikut, yaitu pada uji coba aitem skala gaya hidup sehat dengan jumlah aitem awal sebanyak 28 aitem dengan rentang koefisien korelasi 0,025-0,547 dan koefisien realibilitas sebesar 0,840 , sehingga setelah 2 aitem gugur dibawah 0,254 menjadi 26 aitem dengan rentang koefisien korelasi 0,256-0,613 dan koefisien realibilitas sebesar 0,846. Pada skala tingkat stres rentang koefisien korelasi 0,291-0,785 dan koefisien realibilitas sebesar 0,913 menandakan tidak ada aitem yang gugur. Pada skala strategi coping stres rentang koefisien korelasi 0,158-0,559 dan koefisien realibilitas sebesar 0,864, sehingga 2 aitem harus digugurkan menjadi sebanyak 26 aitem dengan rentang koefisien korelasi 0,298-0,580 dan koefisien realibilitas sebesar 0,868. Berdasarkan hasil validitas dan realibilitas menandakan bahwa nilai validitas setiap aitem di dalam skala sudah memenuhi nilai diatas 0,254 (nilai harga $\mathrm{r}$ kritis product moment) yang menandakan bahwa setiap aitem di dalam skala sudah memenuhi untuk mengukur apa yang ingin diukur pada penelitian, dan pada nilai realibilitas pada ketiga skala ukur berada di atas nilai koefisien realibilitas berkisar antara 0,801,00 , yang menandakan tingkat keterandalan setiap alat ukur sangat tinggi, sehingga dapat dipercaya untuk mengukur aitem-aitem pada variabel (Sugiyono, 2007).

Berbeda dengan menguji asumsi koefisien validitas dan realibilitas, syarat uji data normalitas dan linieritas adalah terkumpulnya semua data yang disebarkan sesuai dengan jumlah sampel yang telah ditentukan, sehingga menggunakan jumlah sampel responden sebanyak 317 siswa. Hasil uji normalitas pada sebaran setiap skala adalah sebagai berikut : sebaran data pada variabel gaya hidup sehat memiliki nilai signifikansi dengan probabilitas sebesar 0,174 atau memiliki probabilitas diatas $0,05(\mathrm{p}>0,05)$ sehingga skala gaya hidup sehat tergolong ke dalam kriteria distribusi normal, sebaran data pada variabel tingkat stres memiliki nilai signifikansi dengan probabilitas sebesar 0,544 atau memiliki probabilitas diatas $0,05(p>0,05)$ sehingga skala tingkat stres tergolong ke dalam kriteria distribusi normal, sebaran data pada variabel strategi coping stres kelompok problem memiliki nilai signifikansi dengan probabilitas sebesar 0,082 atau memiliki probabilitas diatas $0,05 \quad(\mathrm{p}>0,05)$ sehingga skala strategi coping pada kelompok problem tergolong ke dalam kriteria distribusi normal, dan sebaran data pada variabel strategi coping stres kelompok emotion memiliki nilai signifikansi dengan probabilitas sebesar 0,200 atau memiliki probabilitas diatas $0,05 \quad(p>0,05)$ sehingga skala strategi coping pada kelompok emotion tergolong ke dalam kriteria distribusi normal.

Pada hasil uji linieritas, peneliti membagi hasil uji linieritas menjadi 2 kelompok, yaitu kelompok strategi problem focused coping dengan nilai probabilitas sebesar 0,000 dan kelompok strategi emotion focused coping dengan nilai probabilitas sebesar 0,000, yang dimana kedua kelompok memiliki nilai probabiltas lebih kecil dari $0,05 \quad(\mathrm{p}<0,05)$ sehingga dikatakan bahwa hubungan antara skor variabel gaya hidup sehat dengan variabel tingkat stres pada kedua kelompok strategi coping stres berorientasi dengan masalah dan emosi telah menunjukkan adanya garis yang sejajar atau lurus. Metode stratistik yang digunakan untuk membagi kelompok pada variabel strategi coping stres adalah menggunakan analisis z-score, sehingga didapatkan pada tabel deskriptif pada kelompok siswa termasuk ke dalam kelompok problem focused coping adalah sebanyak 143 orang $(45,1 \%)$ dan kelompok emotion focused coping adalah sebesar 112 orang $(35,3 \%)$, sedangkan kelompok lainnya adalah termasuk ke dalam kelompok yang dominan menggunakan problem dan emotion focused coping secara bersamaan sebanyak 62 orang $(19,6 \%)$.

Tabel 1.

Deskriptif Kelompok Strategi Coping Stres

\begin{tabular}{lcc}
\hline Kelompok Strategi Coping Stres & Jumlah (N) & $\%$ \\
\hline Problem focused coping & 143 & $45,1 \%$ \\
\hline Emotion focused coping & 112 & $35,3 \%$ \\
\hline Problem \& Emotion focused coping & 62 & $19,6 \%$ \\
\hline
\end{tabular}

Deskripsi data tambahan penunjang melihat besaran hubungan analisis regresi linier sederhana setelah dilakukan kategorisasi skor pada kedua variabel gaya hidup sehat dan tingkat stres adalah sebagai berikut :

Tabel 4.

\begin{tabular}{ccccc}
\multicolumn{5}{c}{ Kategorisasi Skor Variabel Gaya Hidup Sehat } \\
\hline Variabel & Rentang Nilai & Kategori & Responden & Persentase \\
\hline & $\mathrm{x} \leq 64,3$ & Sangat & 22 orang & $6.9 \%$ \\
& & Rendah & \\
\cline { 2 - 5 } Gaya Hidup \\
\cline { 2 - 5 } Sehat & $64,3<\mathrm{x} \leq 72,3$ & Rendah & 87 orang & $27,5 \%$ \\
\cline { 2 - 5 } & $72,3<\mathrm{x} \leq 78,6$ & Sedang & 93 orang & $29.3 \%$ \\
\cline { 2 - 5 } & $78,6<\mathrm{x} \leq 86,6$ & Tinggi & 95 orang & $30 \%$ \\
\cline { 2 - 5 } & $86,6<\mathrm{x}$ & Sangat & 20 orang & $6.3 \%$ \\
& Tinggi & & \\
\hline & Jumlah & 317 orang & $100 \%$ \\
\hline
\end{tabular}




\section{N. A. K. WIBAWA DAN P. N. WIDIASAVITRI}

Dari tabel kategorisasi skor variabel gaya hidup sehat rata-rata presentase tertinggi berada pada kategori skor gaya hidup sehat yang tinggi dengan presentase sebesar 30\% atau 95 orang yang menerapkan gaya hidup sehat.

\begin{tabular}{|c|c|c|c|c|}
\hline Variabel & Rentang Nilai & Kategori & Responden & Persentase \\
\hline \multirow{6}{*}{$\begin{array}{c}\text { Tingkat } \\
\text { Stres }\end{array}$} & $x \leq 39,714$ & $\begin{array}{l}\text { Sangat } \\
\text { Rendah }\end{array}$ & 15 orang & $4,7 \%$ \\
\hline & $39,714<x \leq 50$ & Rendah & 86 orang & $27,2 \%$ \\
\hline & $50<x \leq 60,5$ & Sedang & 112 orang & $35,3 \%$ \\
\hline & $60,5<\mathrm{x} \leq 65,6$ & Tinggi & 57 orang & $18 \%$ \\
\hline & $65,6<\mathrm{x}$ & $\begin{array}{l}\text { Sangat } \\
\text { Tinggi }\end{array}$ & 45 orang & $14,8 \%$ \\
\hline & Jumlah & & 317 orang & $100 \%$ \\
\hline
\end{tabular}

Dari tabel kategorisasi skor variabel tingkat stres rata-rata presentase tertinggi berada pada kategori skor tingkat stres yang sedang dengan presentase sebesar 35,3\% atau sebanyak 112 orang yang sedang berada pada tingkatan stres sedang. Setelah data dikategorisasikan dan dikelompokan menjadi 2 kelompok problem focused coping dan emotion focused coping, maka uji asumsi untuk melakukan analisis data terpenuhi, dilanjutkan dengan uji hipotesis untuk melihat analisis uji statistik regresi linier sederhana. Peneliti akan melihat nilai uji $\mathrm{F}$, persamaan regresi, hasil uji $\mathrm{T}$, dan koefisien determinasi penelitian pada kedua kelompok berbeda, yaitu problem focused coping dan emotion focused coping. Hasil uji F pada kelompok problem focused coping dan emotion focused coping adalah sebagai berikut :

\section{Tabel 2.}

Hasil Analisis Regresi Linier pada Kelompok
\begin{tabular}{lcc}
\multicolumn{2}{c}{ Problem } & Focused Coping \\
\hline Model & F & Sig \\
\hline Regression & 14,966 & 0,000 \\
\hline Residual & & \\
\hline Total & & \\
\hline
\end{tabular}

Pada tabel uji $\mathrm{F}$ pada kelompok problem focused coping, ditemukan harga F hitung sebesar 14,966 kemudian dikonsultasikan dengan harga $\mathrm{F}$ tabel sebesar 3,06 (Sugiyono, 2007). F hitung lebih besar dari $F$ tabel $(14,966>3,06)$ dan nilai signifikansi kurang dari $0,05(0,000<0,05)$, maka garis regresi dapat dipercaya untuk dapat meramalkan kontribusi variabel independen yakni variabel gaya hidup sehat terhadap variabel dependen yakni variabel tingkat stres pada kelompok problem focused coping.

\begin{tabular}{cccccc}
\multicolumn{6}{c}{ Tabel 3. } \\
\multicolumn{5}{c}{$\begin{array}{c}\text { Persamaan Garis Regresi dan Hasil Uji T pada Kelompok } \\
\text { Problem Focused Coping }\end{array}$} \\
\hline \multirow{2}{*}{ Model } & \multicolumn{2}{c}{$\begin{array}{l}\text { Unstandardized } \\
\text { Coefficient }\end{array}$} & $\begin{array}{c}\text { Standardized } \\
\text { coefficient }\end{array}$ & & \\
\cline { 2 - 6 } & $\mathrm{B}$ & Std.error & $\mathrm{B}$ & $\mathrm{T}$ & Sig. \\
\hline Konstanta & 75,018 & 9,092 & & 8,251 & 0,000 \\
\hline Ykomitmen & $-0,556$ & 0,120 & $-0,177$ & $-2,133$ & 0,000 \\
\hline
\end{tabular}

Pada tabel hasil uji $t$, dapat diketahui bahwa nilai konstanta $(\mathrm{a})=75,018$ dan beta $=0,556$ serta taraf signifikansi sebesar 0,000. Persamaan regresi yang diperoleh berdasarkan hasil dari tabel uji $\mathrm{T}$ adalah $\mathrm{Y}=75,018-0,556 \mathrm{X}$ yang dapat diartikan bahwa setiap penambahan satu poin pada variabel gaya hidup sehat, maka akan menurunkan poin pada variabel tingkat stres sebesar 0,556 poin. Tanda negatif pada nilai beta menyatakan bahwa hubungan variabel bebas dengan variabel terikat berbeda arah, yakni setiap kenaikan pada variabel bebas (X) akan mengakibatkan penurunan variabel terikat (Y), begitu juga sebaliknya jika terjadi penurunan pada variabel bebas $(\mathrm{X})$ akan mengakibatkan peningkatan pada variabel terikat $(\mathrm{Y})$.

Tabel 4

Koefisien Determinasi Penelitian pada Kelompok Problem Focused Coping

\begin{tabular}{cccc}
\hline$R$ & $R$ Square & $\begin{array}{c}\text { Adjusted } R \\
\text { square }\end{array}$ & $\begin{array}{c}\text { Std. error of } \\
\text { the estimate }\end{array}$ \\
\hline 0,876 & 0,804 & 0,798 & 0,85442 \\
\hline
\end{tabular}

Dari tabel hasil uji koefisien determinasi $\left(\mathrm{R}^{2}\right)$ diatas, dapat diketahui bahwa terdapat hubungan antara variabel independen yaitu gaya hidup sehat dalam memprediksi variabel dependen yaitu tingkat stres pada kelompok problem focused coping. Nilai R sebesar 0,876 berada di rentang $0,80-$ 1,00 sehingga dikategorikan memiliki hubungan yang sangat kuat (Sugiyono, 2007). Maka dari itu, nilai $\mathrm{R}$ memiliki arti bahwa hubungan antara gaya hidup sehat pada kelompok strategi problem focused coping dalam memprediksi variabel dependen yaitu tingkat stres yang tergolong sangat kuat.

Koefisien determinasi yang dapat dilihat dari nilai $\left(\mathrm{R}^{2}\right)$ menunjukkan seberapa besar kemampuan variabel independen yakni gaya hidup sehat pada kelompok strategi problem focused coping dapat menjelaskan variabel dependen berupa tingkat stres (Sugiyono, 2007). Koefisien determinasi $\left(\mathrm{R}^{2}\right)$ adalah sebesar 0,804, yang mengandung arti bahwa gaya hidup sehat berkontribusi terhadap tingkat stres sebesar $80,4 \%$, dan sisanya sebesar $19,6 \%$ dapat dijelaskan oleh variabel lain yang tidak diteliti dalam penelitian ini. Koefisien determinasi yang dapat dilihat dari nilai $\left(\mathrm{R}^{2}\right)$ menunjukkan seberapa besar kemampuan variabel independen yakni gaya hidup sehat pada kelompok strategi problem focused coping dapat menjelaskan variabel dependen berupa tingkat stres (Sugiyono, 2007). Koefisien determinasi $\left(\mathrm{R}^{2}\right)$ adalah sebesar 0,804, yang mengandung arti bahwa gaya hidup sehat berkontribusi terhadap tingkat stres sebesar $80,4 \%$, dan sisanya sebesar 19,6\% dapat dijelaskan oleh variabel lain yang tidak diteliti dalam penelitian ini. Dilanjutkan dengan penjabaran pada kelompok emotion focused coping sebagai pembanding analisis regresi linier sederhana adalah sebagai berikut : 
Tabel 2.

Hasil Analisis Regresi Linier pada Kelompok Emotion Focused Coping

\begin{tabular}{lcc}
\hline Model & F & Sig \\
\hline Regression & 13,251 & 0,000 \\
\hline Residual & & \\
\hline Total & & \\
\hline
\end{tabular}

Pada tabel uji F pada kelompok emotion focused coping, ditemukan harga $\mathrm{F}$ hitung sebesar 13,251 kemudian dikonsultasikan dengan harga $\mathrm{F}$ tabel sebesar 3,06 (Sugiyono, 2007). F hitung lebih besar dari F tabel $(13,251>3,06)$ dan nilai signifikansi kurang dari $0,05(0,000<0,05)$, maka garis regresi dapat dipercaya untuk dapat meramalkan kontribusi variabel independen yakni variabel gaya hidup sehat terhadap variabel dependen yakni variabel tingkat stres pada kelompok emotion focused coping.

\begin{tabular}{|c|c|c|c|c|c|}
\hline \multicolumn{6}{|c|}{$\begin{array}{c}\text { Tabel } 3 . \\
\text { Persamaan Garis Regresi dan Hasil Uji T pada Kelompok } \\
\text { Emotion Focused Coping }\end{array}$} \\
\hline \multirow[t]{2}{*}{ Model } & \multicolumn{2}{|c|}{$\begin{array}{l}\text { Unstandardized } \\
\text { Coefficient }\end{array}$} & \multirow{2}{*}{$\begin{array}{c}\text { Standardized } \\
\text { coefficient } \\
\text { B }\end{array}$} & \multirow[b]{2}{*}{$\mathrm{T}$} & \\
\hline & B & Std.error & & & Sig. \\
\hline Konstanta & 88,748 & 9,186 & & 9,661 & 0,000 \\
\hline Ykomitmen & $-0,440$ & 0,121 & $-0,328$ & $-3,640$ & 0,000 \\
\hline
\end{tabular}

Pada tabel hasil uji t pada kelompok emotion focused coping, dapat diketahui bahwa nilai konstanta (a) $=88,748$ dan beta $=-0,440$, serta taraf signifikansi sebesar 0,000 . Persamaan regresi yang diperoleh berdasarkan hasil dari tabel uji adalah $\mathrm{Y}=88,748$ - 0,440X yang menyatakan bahwa setiap penambahan satu poin pada variabel gaya hidup sehat, maka akan menurunkan poin pada variabel tingkat stres sebesar 0,440 poin. Tanda negatif pada nilai beta menyatakan bahwa hubungan variabel bebas dengan variabel terikat berbeda arah, yakni setiap kenaikan pada variabel bebas (X) akan mengakibatkan penurunan variabel terikat (Y), begitu juga sebaliknya jika terjadi penurunan pada variabel bebas (X) akan mengakibatkan peningkatan pada variabel terikat $(\mathrm{Y})$.

$$
\text { Tabel } 4 .
$$

Koefisien Determinasi Penelitian pada Kelompok Emotion Focused Coping

\begin{tabular}{cccc}
\hline$R$ & $R$ Square & $\begin{array}{c}\text { Adjusted } R \\
\text { square }\end{array}$ & $\begin{array}{c}\text { Std. error of } \\
\text { the estimate }\end{array}$ \\
\hline 0,844 & 0,712 & 0,757 & 0,98799 \\
\hline
\end{tabular}

Sedangkan pada kelompok emotion focused coping, ditemukan nilai $\mathrm{R}$ sebesar 0,844 yang berada di rentang 0,801,00 sehingga dikategorikan memiliki hubungan yang sangat kuat (Sugiyono, 2007). Koefisien determinasi $\left(\mathrm{R}^{2}\right)$ ialah sebesar 0,712, yang mengandung arti bahwa gaya hidup sehat berkontribusi terhadap tingkat stres sebesar 71,2\%, dan sisanya sebesar $28,8 \%$ dapat dijelaskan oleh variabel lain yang tidak diteliti dalam penelitian ini. Maka dari itu, nilai $\mathrm{R}$ memiliki arti bahwa hubungan antara gaya hidup sehat pada kelompok strategi emotion focused coping dalam memprediksi variabel dependen yaitu tingkat stres yang tergolong sangat kuat.

Berdasarkan penjabaran tabel analisis sebelumnya, dapat disimpulkan bahwa besar nilai signifikansi yang diperoleh pada kelompok problem focused coping adalah sebesar 0,000 yang lebih kecil dari $0,05(\mathrm{p}<0,05)$ dan begitu juga nilai signifikansi yang diperoleh pada kelompok emotion focused coping adalah sebesar 0,000 yang lebih kecil dari 0,05 $(\mathrm{p}<0,05)$ sehingga hipotesis diterima. Sedangkan apabila dilihat dari nilai t pada kelompok problem focused coping, didapatkan bahwa t hitung sebesar 2,133 yang lebih besar dari $\mathrm{t}$ tabel sebesar 1,960, dan begitu juga nilai t pada kelompok emotion focused coping, didapatkan bahwa t hitung sebesar 3,640 yang lebih besar dari t tabel sebesar 1,980, sehingga hipotesis diterima. Untuk melihat kelompok pada strategi coping stres yang lebih dominan dalam melihat hubungan antara gaya hidup sehat dengan tingkat stres adalah dengan membandingkan nilai korelasi $\mathrm{R}$, dimana pada kelompok problem focused coping nilai $\mathrm{R}$ yang di dapat adalah 0,876 dan pada kelompok emotion focused coping adalah sebesar 0,844 sehingga kelompok yang lebih baik penggunaan strategi coping pada hubungan antara gaya hidup sehat dengan tingkat stres adalah kelompok problem focused coping daripada kelompok emotion focused coping dengan besaran nilai $\mathrm{R}$ adalah $0,876>0,844$.

Berdasarkan hasil hipotesis diatas, maka didapatkan asumsi peneliti yang membuktikan bahwa Hipotesis alternatif (Ha) diterima, yang menyatakan terdapat hubungan antara gaya hidup sehat dengan tingkat stres siswa kelas XII SMA Negeri di Denpasar menjelang Ujian Nasional berdasarkan strategi coping stres.

\section{PEMBAHASAN DAN KESIMPULAN}

Hipotesis dalam penelitian ini menyebutkan bahwa terdapat hubungan antara gaya hidup sehat dengan tingkat stres siswa kelas XII SMA Negeri di Denpasar berdasarkan strategi coping stres. Dapat disimpulkan bahwa untuk melihat kelompok pada strategi coping stres yang lebih dominan dalam melihat hubungan antara gaya hidup sehat dengan tingkat stres adalah dengan membandingkan nilai $\mathrm{R}$, dimana pada kelompok problem focused coping nilai $\mathrm{R}$ yang di dapat adalah 0,876 dan pada kelompok emotion focused coping adalah sebesar 0,844 sehingga kelompok yang lebih baik penggunaan strategi coping pada hubungan antara gaya hidup sehat dengan tingkat stres adalah kelompok problem focused coping daripada kelompok emotion focused coping dengan besaran nilai $\mathrm{R}$ adalah 0,876>0,844. Hasil korelasi juga berlawanan arah, dimana pada koefisien korelasi bertanda negatif pada kedua kelompok, dimana nilai pada kelompok problem focused coping sebesar -0,556 dan pada kelompok emotion focused coping sebesar -0,440 yang menyatakan 


\section{N. A. K. WIBAWA DAN P. N. WIDIASAVITRI}

bahwa jika nilai pada variabel gaya hidup sehat maka nilai pada variabel tingkat stres akan mengalami penurunan, begitu juga sebaliknya.

Jika dijabarkan secara luas, terdapat hubungan yang tergolong sangat kuat pada variabel gaya hidup sehat dengan tingkat stres pada masing-masing kelompok strategi coping, yaitu problem focused coping dan emotion focused coping. Namun, arah korelasi yang dibentuk adalah berlawanan arah, yang artinya adalah jika individu menerapkan gaya hidup sehat yang baik, maka tingkat stres yang dialami siswa kelas XII SMA Negeri di Denpasar menjelang Ujian Nasional akan menurun, baik individu yang tergolong ke dalam kelompok strategi problem focused coping dan emotion focused coping. American Psychological Association (2013) melakukan survei sejak tahun 2007 mengenai "Mind/Body Health" di Amerika dan ditemukan hasil bahwa sikap dan persepsi individu mengenai stres di kota-kota besar Amerika berdampak pada bagaimana individu tetap menjaga gaya hidup yang baik untuk memanajemen individu keluar dari stres dan dampak stres terhadap kehidupan individu, yang ditandai dengan perhatian serius pada implikasi stres fisik dan emosional yang tidak terlepas pada hubungannya dengan tubuh dan pikiran.

American Psychological Association melampirkan dalam laporannya bahwa gaya hidup dan perilaku menjadi sumber dan tantangan Amerika untuk meningkatkan penyediaan fasilitas kesehatan "Health Care System" yang bertujuan untuk mengontrol dan mencegah beberapa penyakit yang diakibatkan tidak sedikitnya bersumber dari stres melalui perilaku dan gaya hidup sehat. Dapat disimpulkan dari keterangan diatas bahwa hubungan antara kesehatan psikologis dan kesehatan fisik serta bagaimana individu mampu menjaga perilaku dan gaya hidup sehatnya melalui manajemen strategi koping stres yang baik, maka akan berpengaruh terhadap kesehatan dan kesejahteraan individu secara garis besar dengan perhatian yang serius dari lembaga yang bergerak di bidang kesehatan melalui peningkatan fasilitas "Health Care System".

Smith \& Pergola (2006) menunjukan bahwa setiap individu semasa hidupnya akan mengalami dan mendapatkan stres, ditambahkan lagi stres berlebih akan muncul ketika individu sedang mengalami kondisi tubuh, mental dan fisik yang lemah. Sehingga dapat disimpulkan bahwa masyarakat sudah peduli terhadap bahaya stres yang berdampak langsung secara positif terhadap kesehatan individu, sehingga diperlukan dukungan dan perhatian yang lebih tidak hanya dari lembaga kesehatan dalam menyebarkan informasi, namun masyarakat secara khususnya harus mampu mengaplikasikan pengelolaan stres melalui perilaku dan gaya hidup sehat dan penerapan strategi koping stres yang baik dalam keseharian beraktivitas. Sehingga dari berbagai sumber informasi yang didapat oleh peneliti, korelasi yang ditemukan peneliti sebesar 0,876 dan 0,844 antara variabel gaya hidup sehat dan tingkat stres pada masing-masing kelompok strategi koping stres yang tergolong hubungan korelasi sangat kuat untuk mendukung penerimaan hipotesis yang diajukan peneliti, namun berkorelasi dengan lajur korelasi yang berlawanan arah yang ditandai dengan semakin individu menerapkan gaya hidup sehat yang baik maka akan semakin menurunkan tingkat stres yang dialami individu.

Beberapa indikator yang digunakan oleh peneliti menjadi pertimbangan dalam melihat dan memprediksi gaya hidup sehat yang diterapkan siswa SMA Negeri kelas XII berhubungan dengan tingkat stres yang dialami siswa terkait dengan Ujian Nasional, yaitu kebugaran fisik dalam berolahraga mampu untuk memelihara kesehatan mental dan fisik individu. Taylor (2009) menyatakan bahwa individu yang rajin berolahraga akan mampu untuk mengaktifkan Hypothalamic Pituitary Adrenocortical (HPA) yang akan melawan munculnya stres dalam tubuh pada sistem saraf simpatik dan pada dasarnya akan memberikan pengaruh pada sistem neurobiologis dan emosional pada pola munculnya stres dalam tubuh. Corbin, Welk, Corbin, dan Welk (2008) juga menambahkan pengaruhnya kita berolahraga secara rutin akan berdampak pada kesehatan psikologis individu, seperti meningkatnya perasaan senang (mood) dan bahagia dalam waktu yang lama (well-being) setelah melakukan aktivitas sehari-hari dan juga akan memberikan pengaruh pada fungsi imun tubuh.

Akbar (2012) menjabarkan kaitannya kebugaran fisik dengan pengelolaan stres individu yang menyatakan bahwa individu yang rajin berolahraga akan mampu merangsang pertumbuhan dan perkembangan jasmani, rohani dan sosial yang terkait dengan struktur anatomis-anthropometris dan fungsi fisiologis, stabilitas emosional dan kecerdasan intelektualnya maupun kemampuannya bersosialisasi dengan lingkungannya, sehingga memunculkan perasaan senang yang meningkatkan aspek sehat secara psikologis sehingga dapat menurunkan stres dibandingkan individu yang jarang berolahraga.

Corbin, Welk, Corbin, dan Welk (2008) melanjutkan indikator gaya hidup sehat pada pola makan seimbang individu yang terkait dengan hubungannya pada tingkat stres, dimana ketika individu mengalami stres yang tinggi maka akan cenderung mengkonsumsi makanan dengan lemak berlebih (seperti coklat, snack, dan daging) dan kurang mengkonsumsi buah atau sayur pada saat sarapan pagi. Stilley (dalam Taylor, 2009) juga menambahkan individu dengan kesadaran dan tingkat inteligensi yang tinggi memiliki kemampuan untuk dapat mengatur pola makan yang baik, berbeda dengan individu pada tingkat depresi, cemas ataupun stres yang tinggi maka akan kurang mampu untuk mengatur pola makan dan akan cenderung mengalami penyakit kolesterol pada usia dini. Taylor (2009) menegaskan bahwa individu dengan tingkat stres yang tinggi dan tidak mampu 
untuk keluar dari pengalaman yang tidak menyenangkan maka kemungkinan besar akan berdampak pada penyakit kelainan pada pola makan, seperti bulimia dan anorexia nervosa. Mudambi (2007) menjelaskan bahwa keadaan individu yang menimbulkan stres baik fisik maupun psikis, akan menimbulkan reaksi kimia luar biasa pada tubuh, dimana hipotalamus mempunyai peranan yang penting dalam mengendalikan metabolisme tubuh, mengatur nafsu makan, metabolisme tubuh dan bertanggung jawab atas respons otak terhadap stres.

Pemanfaatan waktu luang berupa istirahat dan tidur yang cukup berhubungan juga dengan tingkat stres individu. Taylor (2009) menegaskan bahwa individu yang mengalami kejadian stres (stressfull event), akan sulit untuk tidur tepat waktu (insomnia) dan terkadang akan mengalami mimpimimpi buruk (nightmare) jika sudah berada pada fase tidur, akibatnya individu akan cenderung mengkonsumsi obatobatan atau alkohol untuk memenuhi kebutuhan tidurnya. Manajemen stres dan partisipasi spiritual terkait dengan keyakinan religius mempengaruhi kehidupan dan sebagai sumber yang memiliki dasar untuk menemukan makna dalam menyikapi kehilangan dan ketidakmampuan (McFadden dalam Hamdiana, 2009). Shanfranke (dalam Hamdiana, 2009) mengindikasikan bahwa dalam sistem orientasi religius atau dimensi spiritual tidak hanya memberikan jawaban terhadap pertanyaan kehidupan religi secara tegas, namun juga lebih mendasar, membentuk hubungan, melakukan kontruksi yang berdampak terhadap pengalaman individu, termasuk pengalaman yang menyedihkan.

Promosi kesehatan dan perilaku berisiko, seperti perilaku merokok, mengkonsumsi obat-obatan dan alkohol, dan perilaku seks bebas memiliki keterkaitan dengan tingkat stres individu. Taylor (2009) menyatakan bahwa individu yang mengalami kejadian hidup yang negatif, kejadian yang menyebabkan stres kronis, dan tidak adanya dukungan sosial akan cenderung mampu menjerumuskan individu menjadi pecandu alkohol. Alasan individu mengkonsumsi alkohol adalah untuk mengganti emosi negatif (seperti sedih atau marah) menjadi emosi positif (seperti bahagia, gembira, dan senang), dan alkohol mampu mengurangi kecemasan dan meningkatkan harga diri (self-esteem) dalam periode waktu sementara. Perilaku merokok dan stres memiliki interaksi yang sama-sama berbahaya dengan mengkonsumsi alkohol. Corbin, Welk, Corbin, dan Welk (2008) menjelaskan bahwa di dalam rokok terdapat bahan dasar nikotin yang akan meningkatkan detak jantung dan mengurangi perilaku stres individu, namun berdampak negatif pada fungsi pernafasan, kesehatan jantung, dan dapat menyebabkan kematian.

Adanya perbandingan nilai skor $\mathrm{R}$ dari kelompok strategi coping yang berorientasi terhadap masalah (problem focused coping) dan berorientasi terhadap emosi (emotion focused coping) yang diperoleh dalam penelitian yang dilakukan, diperkuat oleh teori dari Sarafino (dalam Hamdiana, 2009) menyatakan bahwa jenis kelamin (gender) akan memberikan pengaruh terhadap individu dalam melakukan coping, dimana dari hasil penelitian yang dilakukan oleh Sarafino ditemukan bahwa jenis kelamin lakilaki akan cenderung menggunakan strategi coping yang berorientasi terhadap masalah (problem focused coping) dan jenis kelamin perempuan akan lebih cenderung menggunakan strategi coping yang berorientasi terhadap emosi (emotion focused coping). Berdasarkan hasil data deskripsi penelitian yang dilakuksan saat ini adalah memenuhi dari persyaratan pernyataan tersebut, dimana pada penelitian ini didapat jumlah total subjek sebanyak 317 orang dengan presentase jenis kelamin ditemukan laki-laki sebanyak 198 orang $(62,5 \%)$ dan perempuan 119 orang (37,5\%). Pada presentase jenis strategi coping yang digunakan pada strategi coping yang berorientasi pada masalah (problem focused coping) adalah sebanyak 143 orang $(45,1 \%)$, berorientasi pada emosi (emotion focused coping) adalah 112 orang (35,3\%), dan berorientasi menggunakan strategi coping keduanya (problem dan emotion focused coping) adalah sebanyak 62 orang (19,6\%).

Teori yang mendukung keterkaitan jenis kelamin dengan penggunaan strategi coping individu ketika menghadapi stres yang berlebihan terdapat dalam pernyataan Sarafino dan Smith (2012) yang menyatakan bahwa pada jenis kelamin laki-laki akan menunjukan reaksi yang lebih berat terhadap stres ketika mendapatkan tantangan terhadap kompetensi atau kemampuan dibandingkan dengan jenis kelamin perempuan dan kecenderungan laki-laki akan menunjukan respon fight or flight yang memiliki arti seseorang akan melawan situasi yang mengancam tersebut sebagai sebuah tantangan atau akan menjauhi situasi yang menyebabkan stres. Lain hal dengan perempuan yang akan menunjukan reaksi yang lebih berat terhadap stres ketika mendapatkan tantangan terhadap sikap kasih sayang dan percintaan, yang kecenderungan akan menunjukan respon tend and befriend untuk meningkatkan dukungan sosial dalam menghadapi situasi yang menyebabkan stres. Sehingga dapat ditarik kesimpulan bahwa tingginya presentase pada kelompok yang menggunakan strategi problem focused coping lebih banyak dibandingkan dengan kelompok strategi emotion focused coping dipengaruhi oleh lebih banyaknya jumlah kelompok individu yang berjenis kelamin laki-laki dibandingkan dengan kelompok perempuan.

Berdasarkan hasil dan pembahasan maka dapat disimpulkan bahwa ada hubungan yang negatif dan signifikan antara gaya hidup sehat dengan tingkat stres siswa kelas XII SMA Negeri di Denpasar menjelang Ujian Nasional berdasarkan strategi coping stres, baik dari kelompok problem focused coping dan emotion focused coping. Hubungan yang negatif menandakan bahwa jika gaya hidup sehat diterapkan oleh siswa meningkat maka tingkat stres yang dialami siswa 


\section{N. A. K. WIBAWA DAN P. N. WIDIASAVITRI}

kelas XII SMA Negeri di Denpasar akan menurun, baik siswa tersebut berasal dari kelompok yang berfokus pada problem focused coping atau emotion focused coping. Namun ada juga faktor-faktor lain yang dapat mempengaruhi hubungan antara gaya hidup sehat dengan tingkat stres individu berdasarkan strategi coping stres, seperti faktor demografi, nilai-nilai budaya daerah, personal control, tipe kepribadian seseorang, pengaruh lingkungan sosial, gejala-gejala sakit, sistem pada akses kesehatan, faktor kognitif, penghalang yang mendukung lemahnya perilaku sehat.

Saran praktis kepada siswa yang menghadapi stres menjelang Ujian Nasional adalah siswa diharapkan mampu menggunakan strategi coping yang tepat sesuai dengan kemampuan diri individu terhadap situasi yang menekan dengan tetap memelihara gaya hidup yang sehat sebagai penunjang menurunnya tingkat stres siswa SMA kelas XII, siswa juga dapat melakukan beberapa hal seperti berolahraga teratur, mengkonsumsi makanan dengan nutrisi seimbang, kegiatan produktif dan sosial, memanfaatkan waktu istirahat dengan baik, kegiatan sehari-hari yang tergolong penerapan pola hidup sehat, dan tidak berhubungan dengan rokok, alkohol, ataupun obat terlarang. Melalui fakta-fakta yang sering terjadi pada sistem pelaksanaan Ujian Nasional yang berubah-ubah setiap tahunnya, peneliti menyarankan kepada lembaga-lembaga pemerintahan di bidang pendidikan untuk lebih memperhatikan dan mengevaluasi kembali standarisasi yang digunakan sebagai penentu kelulusan sehingga mampu meminimalisasi dampak negatif pada siswa. Karena menjadi faktor stres utama yang dialami siswa SMA kelas XII mnejelang pelaksanaan Ujian Nasional.

Saran praktis kepada peneliti selanjutnya yang tertarik untuk menindak lanjuti penelitian ini disarankan untuk mengontrol variabel lain sebagai pembanding ataupun untuk menciptakan penemuan baru dalam menguji suatu teori. Beberapa hal yang dapat disarankan untuk penelitian selanjutnya adalah untuk melihat keterkaitan tingkat sosial ekonomi dan pendidikan keluarga, batasan dukungan sosial keluarga, keadaan sistem pembelajaran di sekolah dan nasional, dan faktor demografik subjek penelitian. Peneliti juga mengharapkan pada penelitian berikutnya menggunakan analisa metodologi yang berbeda dengan menggunakan metode penelitian true experiment untuk lebih meyakinkan kaitannya dengan korelasi ketika ketiga variabel tersebut digabungkan.

\section{DAFTAR PUSTAKA}

Afifah, R. (2013, Mei 24). Ini dia 12 siswa dengan nilai tertinggi di UN 2013. Diakses Mei 30, 2013, dari Kompas.com: http://edukasi.kompas.com/read/2013/05/24/10350387/Ini.Dia.1 2.Siswa.dengan.Nilai.Tertinggi.di.UN.2013
Akbar, M. S. (2012). Profil gaya hidup sehat mahasiswa fakultas pendidikan olahraga dan kesehatan (FPOK). skripsi S1 (pp. 166). Bandung: Universitas Pendidikan Indonesia.

Akuntono, I. (2012, Agustus 12). Mekanisme penyaluran BOS SMA sama dengan SD/SMP. Diakses Januari 2013, dari Kompas.com:

http://edukasi.kompas.com/read/2012/08/12/09211956/Mekanis me.Penyaluran.BOS.SMA.Sama.dengan.SD/SMP

American Psychological Association. (2013). Stress in America : Missing the Health Care Connection. American: Harris Interactive Inc.

Angraeni, T., \& Cahyanti, I. Y. (2012). Perbedaan psychological well-being pada penderita diabetes tipe 2 usia dewasa madya ditinjau dari strategi coping. Jurnal Psikologi Klinis dan Kesehatan Mental vol. 1 No. 02, 86-93.

Ari. (2012, Maret 18). Lipsus UAN: Bosan \& tertekan demi kelulusan. Diakses Agustus 30, 2012, dari Harian Jogja.com: http://www.harianjogja.com/baca/2012/03/18/lipsus-uan-bosantertekan-demi-kelulusan-171400

Arikunto, S. (2010). Prosedur penelitian: Sebuah pendekatan praktik. Jakarta: PT Rineka Cipta.

Arvianti, K. (2009). Hubungan pengetahuan dan sikap dengan gaya hidup sehat mahasiswa. Skripsi S1 jurusan peminatan promosi kesehatan Fakultas Kesehatan Masyarakat (pp. 1-84). Jakarta: Universitas Indonesia.

Atmalib. (2006). Atmalib: perpustakaan Unika Atmajaya. Diakses Juli 2013, 15, dari Peraturan Menteri Kesehatan RI Nomor 86/MENKES/PER/IV/77 tentang Minuman Keras: https://lib.atmajaya.ac.id/default.aspx?tabID $=61 \& s r c=k \& i d=1$ 62584

Azwar, S. (2012). Penyusunan Skala Psikologi. Yogyakarta: Pustaka Pelajar.

Badudu, A. (2012, Mei 26). Ini 10 siswa sma dan smk peraih nilai un tertinggi. Diakses Januari 20, 2013, dari Tempo.co: http://www.tempo.co/read/news/2012/05/26/079406243

Baker, L. A., Cahalin, L. P., Gerst, K., \& Burr, J. A. (2005). Productive activities and subjective well-being among older adults: The influence of number of activities and time commitment. Social Indicators Research, 73: 431-458.

Bali Post. (2005, Desember 2). UN 2006, syarat lulus makin berat. Diakses Maret 13, 2013, dari Bali Post: http://www.balipost.co.id/BALIPOSTCETAK/2005/12/2/b7.HT $M$

Bloom, M. (1985). Life span development: Basis for preventive and intervening helping. New York: McMilln Publishing Company.

Brewin, C. (1994). Explanation and adaptation in diversity. In B. Smet, Psikologi kesehatan (p. 343). Jakarta: Grasindo.

Brundtland, D. G. (2002). The world health report 2002: Reducing risks, promoting healthy life. France: WHO Library Catalouging in Publication Data.

Corbin, C., Welk, G., Corbin, W., \& Welk, K. (2008). Concept of fitness and wellness: A comprehensive lifestyle approach (Ed.7th). New York: McGrawHill Companies.

Departemen Kesehatan Republik Indonesia. (1997). Manajemen penyuluhan kesehatan masyarakat tingkat puskesmas. Jakarta: Departemen Kesehatan RI.

Disdikpora. (2013). Sistem pendidikan SMA/MA Indonesia. Jakarta: Departemen Pendidikan RI 
Dwiari, K. (2013, Februari Kamis). Remaja, Makanan, dan Kesehatan. Diakses September Rabu, 2013, dari Bali Post Online: http//www.balipost.online.com

Fauziyah, I. (2011). Hubungan pengungkapan diri remaja pada orang tuanya dengan stres di SMP 01 Tulungangung. Skripsi S1. Tulungagung: Universitas Islam Negeri Malang.

Gochman, D. S. (1988). Health behaviour: Emerging research persepective. New York: Plenum Press.

Goodyer. (1988). Stress in childhood and adolescence. In S. Fisher, \& J. Reason, Handbook of life stress, cognition, and health. New York: Jhon Willey \& Sons.

Hamdiana. (2009). Perbedaan tingkat stres dan strategi koping pada lansia yang tinggal di rumah bersama keluarga dan panti sosial tresna wredha kecamatan peusangan kabupaten bireuen nanggroe aceh darussalam. Tesis Ilmu Keperawatan, 1-172.

Hernawati, N. (2006). Tingkat stres dan strategi koping menghadapi stres pada mahasiswa tingkat persiapan bersama tahun akademika 2005/2006 . J.II.Pert.Indon. Vol. 11 (2), 43-49.

Herry. (2008). Hubungan karakteristik, gaya hidup dan asupan faktor gizi terhadap status IMT pada lansia di 3 posbindu kelurahan rangkapan jaya lama. Skripsi S1 (p. 93). Jakarta: Fakultas Kesehatan Masyarakat Universitas Indonesia.

Hill, S. A. (2004). Stress and Coping Among Elderly African Americans. Dissertation Doctor of nursing Science, www.proquest.com/pqdauto, diakses tanggal 30 Agustus 2012.

Hurrelman, K., \& Losel, F. (1990). Basic issues and problem of health in adolescence. In K. Hurrelman, \& F. Losel, Health hazards in adolescents. New York: Walter De Gruyter.

Jannah, N., \& Taganing, N. M. (2006). Desciption of stress and coping strategy in unemployed youths. Undergraduate Program Faculty of Psychology Gunadarma, 1-17.

Kinantie, O. A., Hernawaty, T., \& Hidayati, N. O. (2012). Gambaran tingkat stres siswa SMAN 3 Bandung kelas XII menjelang Uian Nasional 2012. Jurnal Fakultas Ilmu Keperwatan Universitas Padjajaran, 1-12.

Komalasari, G., \& Herdi. (2011). Coping skills untuk mengatasi kecemasan menghadapi ujian nasional pada siswa sekolah menengah atas negeri di provinsi DKI Jakarta. Jurusan Bimbingan dan konseling (pp. 1-21). Jakarta : Universitas Negeri Jakarta.

Lazarus, R. S., \& Folkman, S. (1984). Stress, appraisal, and coping. New York: Springer Publishing Company.

Lovibond, S. H., \& Lovibond, P. F. (1996). The dass: Manual for the depression, anxiety stress scales. Australia: Psychology Foundation of Australia.

Mahagangga, O. (2010, Mei). Tantangan globalisasi terkait dunia pendidikan. Media Udayana Edisi 25, pp. 10-12.

Mudambi, S. R. (2007). Fundamental of foods, nutrition and diet therapy. New York: New Age International.

Nazir, M. (1988). Metode penelitian. Jakarta: Ghalia Indonesia.

Noor, A. Y. (2012). Perbedaan Tingkat perilaku agresi berdasarkan strategi koping pada remaja jalanan griya baca. Skripsi S1 Fakultas Psikologi (pp. 1-79). Malang: Universitas Islam Negeri Maulana Malik Ibrahim.

Notoatmodjo, S. (2007). Kesehatan masyarakat ilmu dan seni. Jakarta: Rineka Cipta.
Papalia, D. E., Olds, S. W., \& Feldman, R. D. (2009). Human Development (Ed. 11th). New York: McGraw-Hil Higher Educationl.

Pormadi. (2011, November 26). Evaluasi un sisdiknas. Diakses januari 13, 2013, dari Pormadiwordpress.com: http://pormadi.wordpress.com/2011/11/26/evaluasi-uusisdiknas/

Prabowo. (2007). Treatment meta music untuk menurunkan stres. Proceeding PESAT (Psikologi, Ekonomi, Sastra, Arsitek \& Sipil) (pp. B65-B70). Jakarta: Universitas Gunadarma.

Pratiwi, A. S. (2009). Penilaian Promosi Kesehatan serta Pola Hidup Sehat Tenaga Kerja HSM dan PP3 PT. Krakatau Steel sebagai Upaya Meningkatkan Derajat Kesehatan Tenaga Kerja. Laporan khusus D3 Hiperkes dan Keselamatan Kerja (pp. 9-10). Surakarta: Fakultas Kedokteran Universitas Sebelas Maret.

Reymond. (2012, Mei 25). Berikut peringkat kelulusan dan ketidaklulusan berdasarkan daerah dari kemendikbud. Diakses Mei 30, 2013, dari Serru.com: http://utama.seruu.com/read/2012/05/25/99788/berikutperingkat-kelulusan-dan-ketidaklulusan-berdasarkan-daerahdari-kemendikbud

Rhismawati, N. L. (2013, Mei 23). Kelulusan UN SMA/MA di Bali 99,95 persen. Diakses Mei 23, 2013, dari ANTARA News.com: http://bali.antaranews.com/berita/38974/kelulusan-un-smamadi-bali-9995-persen

Santrock, J. W. (2013). Life Span Development (Ed. 14th). New York: McGraw-Hill Professional.

Sarafino, E. P. (1990). Helath psychology: Biopsychosocial interaction. In S. Bart, Psikologi Kesehatan. New York: Jhon Wiley \& Sons.

Sarafino, E. P., \& Smith, T. W. (2012). Health psychology: Biopsychosocial interactions (Ed. 7th). Canada: Jhon Wiley \& Sons.

Saraswati, I. (2012). Perbedaan karakteristik usia, asupan makanan, aktivitas fisik, tingkat sosial ekonomi, dan pengetahuan gizi pada wanita dewasa dengan kelebihan berat badan antara di desa dan kota. Studi Ilmu Gizi Fakultas Kedokteran Universitas Dipenogoro, 1-38.

Seiffgekrenke. (1994). Coping and health related behavior. In B. Smet, Psikologi kesehatan (p. 343). Jakarta: Grasindo.

Sharkey, B. J., \& Gaskill, S. E. (2013). Fitness and Health (Ed. 7th). United State of America: Human Kinetics.

Smet, B. (1994). Psikologi Kesehatan. Jakarta: PT Grasindo.

Smith, S., \& Pergola, J. (2006). Stress Management: Preventing stress through lifestyle management. journal of Institute of food and agriculture.

Sugiyono. (2009). Metode penelitian bisnis: Pendekatan kuantitatif, kualitatif dan R\&D. Bandung: Alfabeta.

Sugiyono. (2010). Statistika untuk penelitian. Bandung: Alfabeta.

Taylor, S. E. (2009). Health psychology (Ed. 7th). New York: McGraw Hill Company.

Torkildsen, G. (2005). Leisure and recreation management (Ed. 5th). New York: Madison Avanue.

Virginia, D. (2009). Family Life Education: Board of Education Guidelines and Standards of Learning for Virginia Public Schools. Commonwealth of Virginia, Department of Education. 


\section{N. A. K. WIBAWA DAN P. N. WIDIASAVITRI}

Vlisides, C. E., Eddy, J. P., \& Mozie, D. (1994). Stress and stressors: Definition, identification and strategy for higher education constituents. College Student Journal, 122-124.

Wang, H. F., \& Yeh, M. C. (2005). Stres, coping, and psychological health of vocational high school nursing student associated with a competitive entrance exam. Journal nursing research vol.13 no.2, 106-115.

Weidner, G., \& Messina, C. R. (2012). Cardiovascular reactivity to mental stress. In E. P. Sarafino, \& T. W. Smith, Health psychology: Biopsychosocial interactions (Ed. 7th) (pp. 29-51). Canada: Jhon Wiley \& Sons.

Wijayanti, N. C., Fitria, N., \& Rafiyah, I. (2012). Gambaran strategi koping siswa kelas XII SMAN Jatinagor yang akan menghadapi Ujian nasional. Skripsi S1 (pp. 1-15). Bandung: Fakultas Ilmu Keperawatan Universitas Padjajaran.

Yuliana, S., Hidayati, E., \& Meikawati, W. (2012). Pengaruh terapi musik untuk penurunan tingkat stres pada remaja di yayasan panti asuhan kyai ageng majapahit. Skripsi S1, (pp. 1-57). Malang. 